\title{
Gerwin Strobl
}

\section{Staging the Nazi Assault on Reason: Hanns Johst's Schlageter and the 'Theatre of Inner Experience'}

\begin{abstract}
Hanns Johst's play Schlageter is generally regarded as the most successful piece of Nazi theatre. Following its first performance in the early months of the Third Reich, it dominated German theatrical life throughout 1933 and 1934. This has traditionally been regarded as evidence of the essential conformity of the Third Reich's stage; yet since no other play achieved a similar prominence in the period, Gerwin Strobl finds that line of argument unconvincing, arguing that the success of Schlageter was due to its clever manipulation of its audience's emotions. The play was perfectly suited to the mood of many German theatregoers in 1933, betraying in its plot and characterization considerable psychological insight and a ruthless determination to exploit that insight for Nazi purposes. As such, Schlageter was the prime example of the Third Reich's 'theatre of inner experience', the ultimate aim of whose practitioners was to get German audiences to abandon reason and accept the irrational vision of history underlying the Nazis' ideological project. Gerwin Strobl is Lecturer in Modern German History at Cardiff University, specializing in popular perceptions and propaganda. He is the author of Germanic Isle: Nazi Perceptions of Britain (Cambridge University Press, 2000), has published on Shakespeare in the Third Reich in History Today (May 1997) and the Journal of Contemporary History (July 1999), and is currently writing a study of Nazi theatre.
\end{abstract}

ON 20 April 1933, Germany's new leadership assembled for an evening in the theatre. It was the first time the country had celebrated Hitler's birthday as a national holiday. The day was to end with a theatrical treat for the Führer: the premiere of Hanns Johst's drama Schlageter. Johst had dedicated the play to Hitler. It had then been broadcast by the newly nazified German radio in the runup to the March 1933 elections. ${ }^{1}$ Now it was to be staged for the first time.

The production was clearly as much a political as a cultural event, and the chosen venue reflected this; for the Prussian State Theatre in Berlin had been the Kaiser's court theatre until the revolution of November 1918. Then Leopold Jessner had made it the showcase of the republic's new theatre style. And just as Jessner had used his inaugural production there to celebrate the collapse of Imperial Germany, so now the Nazis were celebrating the fall of the Weimar republic. ${ }^{2}$

Schlageter was, in its own terms, a signal success. The production was polished, the play itself an effective piece of stagecraft. The chief theatre censor in the Third Reich, the Reichsdramaturg Rainer Schlösser, pronounced it a fitting response to those who 'for so long' had 'made fun ... of our cultural ambitions'. ${ }^{3}$ At a personal level, it confirmed Johst's position as the bard of Nazism and advanced the fortunes of many in the cast. ${ }^{4}$

Lothar Müthel, playing the title role, was forgiven his earlier closeness to 'the Jew', Max Reinhardt. Less than two weeks after the first night of Schlageter, he was accepted into the Nazi Party, and was subsequently allowed to direct widely. After the annexation of Austria, he took over the reins at the Burgtheater in Vienna, perhaps the most august theatrical establishment in Central Europe. Veit Harlan, playing Schlageter's friend, was to achieve greatness in Nazi cinema as one of Goebbels's most trusted lieutenants. Meanwhile, the young actress Emmy Sonnemann had caught the eye of the man who hosted the production: the Prime Minister of Prussia. ${ }^{5}$ In due course, Emmy 
Sonnemann would become Mrs Hermann Göring.

Johst himself was admitted into the Prussian Academy by ministerial decree a fortnight after the premiere of Schlageter, and was immediately elected its president. ${ }^{6} \mathrm{He}$ was appointed Prussian State Councillor, was the first recipient of the National Socialist Prize for Arts and Sciences (the 'Nazi Nobel Prize'), and was subsequently also awarded the German National Prize and the Goethe Medal. Within the SS, into which Johst was admitted in November 1935, he rose to the eventual rank of Gruppenführer, the SS equivalent of a general, and he also became a close confidant and personal friend of Himmler.

By 1935 Johst had reached the apex of the Nazi cultural bureaucracy when Goebbels appointed him president of the Reich Chamber of Literature. ${ }^{7}$ The author of Schlageter had achieved the rare feat of being equally showered with honours by Göring, Goebbels, Himmler, and Rosenberg. Given the notorious rivalry between these men and the factions of the party which they represented, such unanimity was certainly striking. ${ }^{8}$

Schlageter itself went on to become the most widely performed new play in the Reich. Most German theatres produced it in the 1933-1934 season, and it was carried into remote corners of Germany by itinerant Nazi players - members of the NS-Kampfbühnen, the party's so-called 'combat troupes'. The play was likewise performed by theatre enthusiasts on open-air stages during the summer months. ${ }^{9}$ In all, productions of Schlageter were mounted in more than a thousand venues in the 1933-1934 season. The play also entered the school curriculum, and German radio broadcast it no fewer than fifteen times in $1933 .{ }^{10}$ If any one drama can be said to have marked the beginning of the Third Reich, it was Schlageter.

\section{Response to a National Humiliation}

Johst's play related the life of the Freikorps leader Albert Leo Schlageter, who had organized the resistance in the Ruhr against the French a decade earlier. ${ }^{11}$ The play ended with a re-enactment of Schlageter's shooting by firing squad. The actor playing Schlageter stood downstage with his back to the audience. Facing him was a platoon of French soldiers who trained their rifles on him - and thus also at the audience. The stage was darkened. Then a strong beam of light shone from backstage towards Schlageter and the audience.

A French soldier approached Schlageter and hit him with the butt of his gun to force him to kneel. This had the effect of allowing the spectators a clear view of the rifles pointing their way. Schlageter then cried out, 'Germany - awake! Turn into a flame, into fire! Burn - beyond imagining! ${ }^{12}$ And, as if in response to that cry, the French execution squad fired off their guns. A volley of shots rang out in the direction of Schlageter and, of course, the audience. All light was extinguished and the curtain fell to a hushed silence. It was perhaps the most effective moment in all of Nazi theatre.

That Schlageter was as much an exercise in propaganda as in theatre has always been obvious. Leopold Jessner's right-hand man, Eckart von Naso, famously described it as 'drumbeat turned drama'. ${ }^{13}$ The reviews at the time reflected this too. They described the play as 'a national event', beyond the measure of traditional criticism. ${ }^{14}$ It is worth pausing, however, to consider how insidiously Johst had manipulated his audiences.

The French invasion of the Ruhr in 1923 over the issue of reparations - had caused a profound national trauma. Germany's industrial heartland had been seized without a shot being fired in its defence. Passive resistance in the region had quickly crumbled under the sheer weight of the French military presence, and the rest of Germany had been forced to watch impotently while foreign soldiers effectively took the inhabitants of the Ruhr hostage.

The Ruhr crisis was not just a military and diplomatic affair: it was a profound national humiliation. The responses to that humiliation were partly shaped by traditional gender roles. The First World War - still very present in people's minds a mere five years after the armistice - had reinforced these 
gender roles. In Germany and elsewhere, males had been cast as the nation's shield and the defenders of her women and children - a view also popularized by German theatre, with its wartime diet of patriotic plays, shows and musical entertainments. ${ }^{15}$ That view of heroic masculinity was now directly challenged by the French invasion. For many German men there was a feeling of having personally failed the Ruhr. It is not too fanciful to suggest that they felt as a father would who had been forced to watch an intruder break into his house and rape his child.

Johst was too adept a writer - and too shrewd a propagandist - to make all this overt. Lesser Nazi (or nationalist) dramatists were writing at that time graphic plays about the collective trauma of the post-war years. Scenes of foreign soldiery raping their way through German lands recurred in several of these. ${ }^{16}$ The intention of their authors was incitement, their vision an eventual war of revenge. Johst shared their hopes of vengeance but his own interest lay not in the foreign arena: he was concerned with the domestic response to the post-war crisis.

There had been in 1923 a theatrical echo to events in the Ruhr. Many German theatres had responded to the news of French forces crossing the Rhine with rapidly staged productions of Schiller's Wilhelm Tell. It was an obvious repertoire choice. Tell was the classic German drama about national resistance (and eventual liberation), and was doubly suitable since Schiller had actually written it in response to an earlier French invasion..$^{17}$ At the time, France under Napoleon had annexed the Low Countries and much of Western Germany, rounding off the expansionist spree by snuffing out Swiss independence. Tell thus carried an unmistakable political message in 1923.

In Berlin Leopold Jessner had produced Wilhelm Tell in the Prussian State Theatre, the very theatre in which Schlageter would be premiered a decade later. As in the case of Schlageter, moreover, the first night of Tell was attended by members of the government. The production was designed, exactly like Schlageter ten years later, as a national

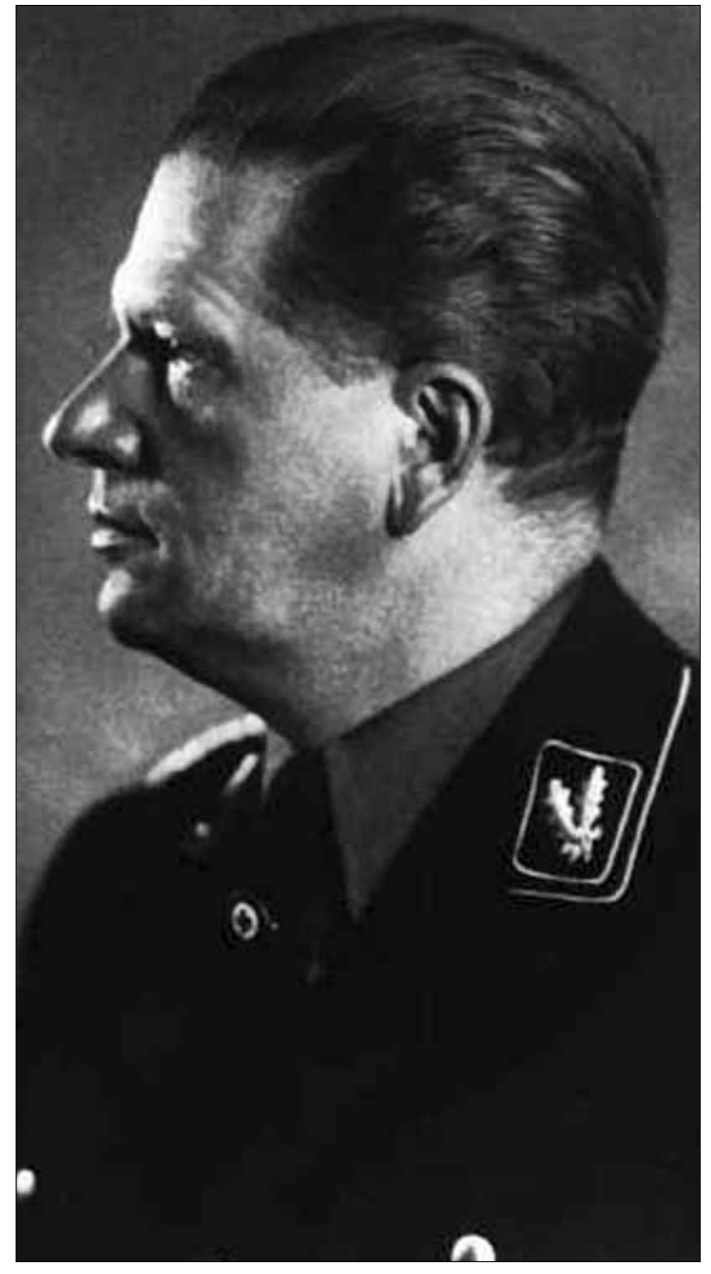

Hanns Johst.

event; and the audience entered into the spirit of the occasion. Patriotic sentiment in 1923 repeatedly erupted in the auditorium. The most striking instance occurred in the scene of the Rütli Oath: members of the audience rose spontaneously and solemnly intoned the famous verse of the oath, pledging themselves to defend their country, as the actors were doing in the play. Theatre and reality had fused. Similar scenes occurred in other German theatres at the time. ${ }^{18}$

This was not jingoism: it was a sign of national impotence. The disarmed and economically crippled Weimar republic utterly lacked the means to resist the French. The German government itself publicly acknowledged as much. Audiences were aware of that. There was little Germans could do 
individually or collectively to help their compatriots in the occupied west. The productions of Wilhelm Tell and the audience reactions to them assumed psychological significance by allowing their audiences to disguise from themselves the humiliation of enforced passivity.

\section{From Guilt to Forgiveness}

It was precisely these psychological ramifications that interested Johst in Schlageter. Ten years on from the occupation of the Ruhr, he sought to rekindle in his audiences the sense of guilt they had felt in 1923. To achieve this, he implied a contrast between events on stage now and the conduct of the spectators then. Schlageter - on stage and in real life had fought the French. The audience had not. The charge of cowardice, of simply abandoning their compatriots to their fate, thus hung in the air.

But Johst - and this was the propagandist's stroke of genius - partly absolved his audiences from that charge. In his play, he deliberately portrayed some exponents of the Weimar republic as well-intentioned in their way. The reviewers of 1933 were struck by this, since it contradicted the established Nazi view. In the words of one critic, Johst's play had offered the hand of forgiveness and reconciliation' to the erstwhile supporters of the republic. ${ }^{19}$

That apparent generosity was not without ulterior motive: it was designed to make the audiences more receptive to Johst's characterization of the drama's hero. Albert Leo Schlageter had been in real life an early exponent of völkisch nationalism. That Johst should have presented him as 'the first soldier of the Third Reich' may not seem particularly surprising; but it is worth remembering that the people watching the play were not necessarily all Nazis.

Most Germans had rejected the far right at the time of the Ruhr crisis and indeed later. Only a few weeks before the first night of Schlageter Germany had gone to the polls; and even in that final democratic election no longer wholly free - the majority of Germans had failed to vote for Hitler. Johst's aim, unmistakably, was to win some of those people over to the Nazi cause. ${ }^{20}$ To that end, Schlageter was presented as someone with whom even non-Nazis could potentially identify. The Schlageter on stage was not a square-jawed nationalist cut-out but a complex, initially hesitant character.

That complexity had a dramatic as well as a propagandistic function. Johst had his protagonist rehearse on stage the views which he suspected many in the audience may have held during the Ruhr crisis. All the doubts and hesitations felt by politically moderate Germans between the wars were there. This allowed the conflict to develop in the play, as Schlageter thrashed out the arguments with his interlocutors. At the same time, the spectators were subtly reassured by hearing their own opinions voiced on stage - and not by the villains, it should be noted, but by the play's hero himself. Then Johst deliberately touched upon the psychological wound in his audience. He left it to a woman - the character created in Berlin by Göring's later wife - to urge German men to stand fast against the French.

This was the moment when the old feelings of guilt could be expected to well up again among the men in the audience. That feeling of guilt was all the more pronounced because the protagonist himself had rehearsed all the arguments in favour of inaction. Johst's Schlageter was effective in transmitting Nazi ideology precisely because he was presented as a reluctant hero: a man slow to take up arms, and who reached for them in the heavy knowledge of likely defeat. That final point was significant.

\section{Entering the Nazi Suicide Pact}

There was always in National Socialism a profoundly pessimistic streak. Defeat in 1918 had seemed to bear out earlier intimations among the far right of national decline. ${ }^{21}$ The manic swagger affected by the leaders of the supposed master race was in part overcompensation; and it continued to alternate with moments of deepest gloom. ${ }^{22}$ At times, this took the form of a pronounced death wish. It was not just Hitler who repeatedly 


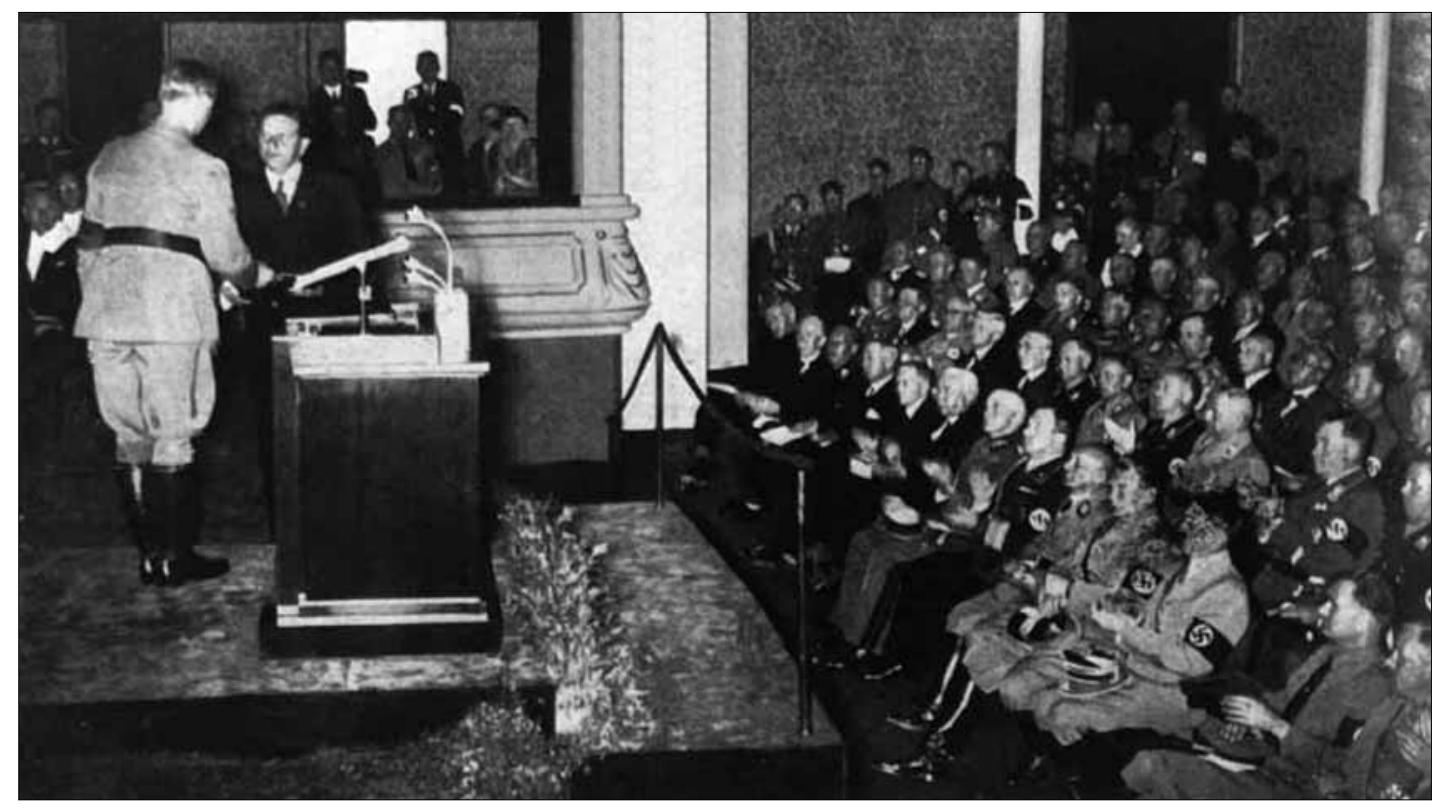

Hanns Johst receives Hitler's commendation, 1935.

luxuriated in the thought of Germany's utter annihilation in battle. For if their destruction as Nazis and as Germans was decreed, then they wanted to embrace it and feel that at least they and their nation had died like men. ${ }^{23}$ 'Life', as Johst himself would later write on the eve of Stalingrad, 'was about learning to die. ${ }^{24}$

Here is the crucial exchange in Johst's play between a still hesitant Schlageter and the army officer urging him to action. When Schlageter declares that fighting the French was surely madness, since renewed armed conflict would not liberate Germany but destroy it utterly, the officer delivers this reply: 'No! Our despair, the unconditional absolute nature of our despair, will destroy the servitude [and] corruption.' ${ }^{25}$ This may seem extraordinary enough by any standards, but there is more. Johst actually has Schlageter warn the officer that in the process Germany would 'turn into a vast graveyard'. The military man agrees, only to add that death is preferable to a life without dignity or honour. Johst's play was about encouraging non-Nazis to enter into that suicide pact.

To put it in modern psychological terms: Johst aimed to induce 'survivor guilt' in his audience, it being a recognized feature of overwhelming disasters that survivors feel undeserving of their own (relative) luck. After the First World War survivor guilt was widespread in the men of all combatant nations. ${ }^{26}$ Those who lived were haunted by the memories of the fallen. The best, many felt, had died. It was this feeling that Johst cynically exploited. Across the graves of the 'Great War' and across Schlageter's corpse on Golzheim heath, Johst effectively confronted his audience with the unspoken question that had been haunting them: 'Why are you still living?'

Schlageter, in other words, was no simple exercise in Nazi propaganda. It displayed considerable awareness of mass psychology. It was its very sophistication that made Schlageter so effective in its day - but it was also this quality that made it such a contemptible play. ${ }^{27}$ Johst had exploited the traditional mechanism of classical drama that of catharsis - for his own nefarious ends. For out of guilt, Johst whispered to his audience, could grow redemption. All that was required was to do the right thing now and not fail Germany a second time. That was why, in the play's final scene, Johst carefully pointed the French guns at the audience as 
well as at the hero. The public should relive emotionally the year 1923. This time, however, they too should join Schlageter in the face of the guns; and, like Schlageter, they should cry a defiant 'Germany awake!'

Those words were, of course, a Nazi Party slogan familiar to all. ${ }^{28}$ Patriotic sentiment and survivor guilt would thus have been transformed into political allegiance to the Nazi leadership. The question, inevitably, is whether Johst's strategy actually worked. There is no conclusive answer. One cannot look into the minds of a nameless crowd decades on: but there is an important clue. In 1923 the theatre audience at the end of Jessner's Wilhelm Tell had spontaneously risen to sing the national anthem. The scene was repeated ten years on at the end of Johst's Schlageter. Only this time 'Deutschland, Deutschland über alles' was followed by a rendition of the 'Horst Wessel-Lied', the Nazi Party anthem.

The final act of a drama, Johst had suggested in an essay some years earlier, should 'take place inside the viewer'. ${ }^{29}$ The aim was to create or strengthen ideological commitment through the medium of the stage. In the words of an official in the Propaganda Ministry, theatre should 'energize' the audiences in the new Reich. ${ }^{30}$ And one of the panjandrums of Nazi culture, the critic Joseph Magnus Wehner, observed specifically about Schlageter, 'The catharsis of this drama lies in the fact that at its end the National Idea has been born inside the viewer. $^{31}$

\section{Theatre in the Service of the State}

Dramas like Johst's had, then, a recognized political function in the service of the Nazi state. $^{32}$ 'The call which has gone out to the theatre is that of "national education",' as another contemporary voice put it. ${ }^{33}$ Johst had created for his masters a politicized theatre that equalled, and perhaps exceeded, in its radicalism the practice of the Weimar republic's most avant-garde directors. In this sense, Schlageter was the Nazi equivalent of Piscator's Gewitter über Gottland. ${ }^{34}$

This should not be reduced to a question of artistic influence. Both the left and the far right in Weimar Germany wished to press theatre into political service. ${ }^{35}$ The parallels in their respective techniques grew out of that shared ambition. ${ }^{36}$ The difference lay in the intended effect. The left sought to induce reflection. Political moderates such as Jessner hoped to strengthen democratic values. The radical anti-democratic left went further: it wished to spur people into action. ${ }^{37}$ Political education delivered on stage would prompt audiences to act in accordance with their supposed class interests. ${ }^{38}$

The Nazis made a more direct appeal to the spectators' emotions. 'The theatre we are aiming for is a theatre of inner experience [Erlebnistheater]', as the dramatist and Propaganda Ministry official Eberhard Wolfgang Möller put it. ${ }^{39}$ And Johst's Schlageter, with its guns trained on the audience in the final scene and its viewers singing the Nazi Party anthem afterwards, was perhaps the most spectacular instance of that Erlebnistheater.

That Nazi theatre should have reflected the anti-intellectualism of the party's ideology may not seem especially surprising. It is worth remembering, however, that the Nazis' mind-set was itself a response to the crisis of German identity after the First World War. This had practical consequences. The party's celebration of instinct and feelings was peculiarly suited to the emotional needs of a traumatized nation.

German audiences in 1933 were not 'normal' theatre audiences. In the previous two decades, they had survived a war of unprecedented savagery; they had seen the mass death of civilians in the winter of 1918 through famine, rampant infant mortality, and the Spanish influenza pandemic; they had experienced defeat, the collapse of their state, national humiliation abroad, occupation of parts of Germany by foreign armies bent on vengeance; civil strife in the streets, entire regions under martial law; the collapse of values, traditions, and symbols; and then not once but twice within a decade - mass destitution, first through hyperinflation and then the slump.

This catalogue of suffering created psychological needs to which the theatre of the 
Weimar republic, and indeed Weimar culture generally, ultimately failed to respond. The chorus of voices criticizing the republic's glacial 'new sobriety' were eloquent testimony of this failure. ${ }^{40}$ So were the empty rows of seats that had bedevilled the republic's theatrical experiment and that had effectively brought it to a close by the early 1930s. ${ }^{41}$ As Johst himself put it, 'the millstones of our misery' had ground down Weimar theatre. ${ }^{42}$

This was not just a Nazi view. After the Second World War, one of the central figures of the then emerging East German cultural bureaucracy, the poet Johannes R. Becher, reached similar conclusions. Becher looked back on the Weimar years and diagnosed a comprehensive failure of the left. They - and Becher includes himself in his verdict - had completely misjudged the situation. They had misread the political developments, and they had been blind to the emotional needs of their fellow-Germans. The artistic approach of the left-wing avant-garde, Becher suggests, had 'isolated [them] from national problems', and had opened the field to the far right. $^{43}$

One of the people ready to exploit this situation in the theatre, the young Nazi dramatist Eberhard Wolfgang Möller, duly proclaimed, 'We have lived through tragedy ... . we now only need to write it down.' ${ }^{44}$ Nazi dramatists in the early stages of the Third Reich did just that: the events of the Weimar republic were revisited in play after play. ${ }^{45}$ Since, in many cases, large audiences attended these plays, one can speak of a nation obsessively probing its wounds.

Schlageter, however, was more than just a theatrical itch. Unlike most other Nazi dramas of the period, which simply used the Weimar past to provide a manichean contrast between republican darkness and the triumph of Nazi light, Johst ostensibly invited his audiences to a moment of reflection. They should examine the history of the past decade. Characters like Schlageter's Social Democrat father, who astonished the critics in 1933 with their robust defence of the republic, were deliberately put on stage to create the illusion of objectivity. That illusion was important to Johst. The dramatic conflict, after all, should not be resolved on stage (let alone beforehand as in so many static Nazi plays) but - as the final act of the drama - in the audience themselves. ${ }^{46}$

If viewers were to emerge transformed by the theatrical experience, this suggests that Johst judged them to be in need of such a transformation. This is no trivial point. It sets Johst apart from many of his competitors and perhaps explains why Schlageter was so effective. Where other Nazi dramatists proceeded from the assumption that their audiences had always opposed the republic, Johst knew better. He was preaching to the unconverted, or perhaps the half-converted. His supposed objectivity was the theatrical bait designed for the so-called Vernunftrepublikaner: that majority of Germans who had been led by their minds (but not their hearts) to back the republic's cause after 1918. It was this constituency that Schlageter sought, so to speak, to reel in.

Johst's strategy therefore was to play by the rules of that constituency, or rather to give the appearance of doing so. Audiences were invited to consider where their belief in reason and dispassionate argument had led them and their country. For as Johst knew, nothing damned the Weimar republic as surely as its own record. None of its promises or predictions had come true. Prosperity had failed to materialize; social harmony at home had proved elusive; and the hopes that the Allies would see in the Weimar republic the emergence of a democratic Germany had been cruelly disappointed. The Allied leaders proved as unyielding to the disarmed German democracy as they would later prove generous to Hitler's threatening Reich.

\section{Rational Economics, Irrational Beliefs}

Schlageter thus relied on the effect of the audience's knowledge of recent German history. As the events of 1923 were rehearsed on stage, the viewers already knew what would follow. They had personal memories of those days. This gave sharper focus to the protagonist's pronouncements. Germans, as Schlageter declared, had fallen after 1918 for 
the 'kitsch of universal brotherhood' ${ }^{47}$ They had put their faith in the 'worldwide community and [the common bonds of] humanity, in the world economy and in Europe, in peace among nations and so on. These entries into the ledger, these kind of calculations', Schlageter explained to his friends, 'were simply false'. Yet there was nothing for it: the majority of Germans believed in them and would go on doing so until the moment of 'bankruptcy'. ${ }^{48}$

The word 'bankruptcy', of course, hit home after the Great Depression. The force of Schlageter's pronouncements was increased, moreover, by Johst's trick of specifically introducing Schlageter as a student of economics. ${ }^{49}$ Johst's Schlageter thus delivered his prediction of 'bankruptcy' in his supposed capacity of economic expert. The collective experience of that bankruptcy on the part of the viewers effectively corroborated the partisan view which Johst put into the mouth of his protagonist. Germany had flourished until she had lost faith in herself in 1918. What followed was common knowledge, or as Schlageter puts it, 'The rest is democracy.' ${ }^{50}$

Johst had changed tactics with Schlageter. Rather than preaching the importance of 'belief' as he had been doing in the past decade to no great effect, he now adopted an indirect approach. He used ostensibly rational arguments to induce his audiences to abandon thought and embrace Nazi 'belief'. The rejection of rationality implicit in the play becomes clear if one compares Johst's account of events in 1923 with the historical facts.

The real-life Schlageter had failed. He had achieved nothing in his campaign against the French. It was not the German resistance that forced France to withdraw from the Ruhr in the end but sustained international pressure on the diplomatic front, not least from France's ally Britain. This had been common knowledge in Weimar Germany. Schlageter's life had thus been pointless, his death in vain. The execution scene at the end of Johst's play combined with the singing of the German National anthem and the Nazi party anthem afterwards effectively suggested otherwise, but the suggestion did not stand up to rational examination. The audiences who genuinely participated in that final act in the theatre had let go of reason, as Johst had hoped they would.

\section{A Voice of Dissent}

However, not all viewers had done so. The Deutsches Literatur Archiv preserves a copy of a remarkable denunciation of Schlageter. ${ }^{51}$ It takes the form of an anonymous letter to Johst written, it seems, in the aftermath of the play's premiere on Hitler's birthday. The letter writer apologized for withholding his name, explaining that in the new Reich the 'instinct of self-preservation' dictated such a course. There follows, over several pages, a detailed rebuttal of Johst's (pseudo-) arguments and an angry denunciation of his methods.

It had been 'an audacity' to put a Nazi slogan in Schlageter's mouth, for it was far from certain that the real Schlageter, were he alive today, would support Hitler's regime. ${ }^{52}$ Exploiting the memory of the victims of the Great War for political purposes, as Johst's play did, was a 'tasteless' act to which no one in the preceding Weimar years had ever stooped. Peace in 1918 had not, moreover, been 'an empty phrase' as Johst suggested, but had been devoutly desired by the majority of Germans. Johst's drama, the writer concluded, was a 'falsification' of history. It was 'dangerous' in its propagation of belief over reason; and it made Johst 'a recruiting agent for [collective] suicide under the command of a band of ... adventurers'.

Such views point to an important fact. Johst's Schlageter could only flourish in a carefully controlled political environment and in very specific historical circumstances. Its outrageous claim that the travails of the German people were the result of its leaders having lacked the courage in 1918 to spill enough blood to avert danger could only be credible if one regarded the economic disasters and the series of national humiliations of the Weimar years as the worst that might befall a nation. At the end of the Third Reich that claim was simply no longer credible.

The play sounded different to Germans after 1945. This was true, above all, of the 
notorious call to spill blood which Johst had put into Schlageter's mouth. Germany's misfortune, the protagonist had suggested, would only end if the German public was ready to call for 'priests' who possessed 'the courage to sacrifice the best', who would 'spill blood, blood, blood', and were 'ready to begin the slaughter'. Twelve years after those lines had first been uttered in the Prussian State Theatre before the assembled Nazi leadership, Germany had been left drenched in blood: the blood of the innocent and her own blood.

More than five million German soldiers and in excess of two million German civilians lay dead; almost every single German city had been reduced to rubble; between twelve and fifteen million Germans had been driven from their ancestral homes in East Central Europe, and a legion of German women - their exact number unknown - had been raped or gang-raped by foreign soldiers seeking vengeance. The reality had vastly exceeded the worried predictions of Johst's anonymous critic in 1933.

Little wonder that the German public turned from Johst decisively after 1945. None of his books - even the less tainted ones achieved a significant readership in post-war Germany, and his dramas vanished almost completely from the German stage. And on the rare occasions when Schlageter has been revived as a theatrical experiment, it has been greeted with a mixture of weariness, distaste, and incomprehension. ${ }^{53}$ The dichotomy between 'emotion' and 'reason' had been dissolved by the actual experience of Nazi rule. Reason and emotion now damned Johst's play equally. History had created a 'final act in the viewer' quite unlike that envisaged by Nazi theatre practitioners in 1933.

\section{Notes and References}

1. See Wolfram Wessels, Hörspiele im Dritten Reich (Bonn: Bouvier, 1985), p. 245.

2. Jessner's 1919 production of Wilhelm Tell included pointed allusions to the Kaiser's reign: see Fritz Kortner's autobiography, Aller Tage Abend (Munich: Kindler, 1959), p. 350-62. The parallel in 1933 with Wilhelm Tell was overt: Johst described Schlageter as a Freiheitsdrama (a drama of liberation), a term usually reserved for Tell.
3. Quoted in Henning Rieschbieter et al., ed., Theater im Dritten Reich (Seelze-Velber: Kallmeyer, 2000), p. 649.

4. With the notable exception of Albert Bassermann, whose Jewish wife made him unacceptable to the regime.

5. Under the German federal system, responsibility for state theatres resided with the respective state governments. The Nazis abolished federalism in 1934 but Göring continued to control the Prussian State Theatre in Berlin as his personal fiefdom.

6 . On the Nazi purge of the Academy, see Werner Mittenzwei, Der Untergang einer Akademie oder die Mentalität des ewigen Deutschen (Berlin: Aufbau, 1992).

7. See the biography by Rolf Düsterberg, Hanns Johst, 'Der Barde der SS': Karrieren eines deutschen Dichters (Paderborn: Schöningh, 2004).

8. The only (temporary) exception was Göring, who sacked Johst as Dramaturg of the Prussian State Theatre in December 1933 when Johst's ideological radicalism had clashed with Göring's more pragmatic approach. For details, see Düsterberg, Hanns Johst, p. 205-9.

9. See the letter by the Mitteldeutsche NS-Bühne to Goebbels, 9 March 1935 (Bundesarchiv Berlin R 55/ 20447, 3); on open-air productions, see Rainer Stommer, Die inszenierte Volksgemeinschaft: die Thingspielbewegung im Dritten Reich (Marburg: Jonas, 1985), p. 26.

10. See Walther Killy, ed., Literatur Lexikon: Autoren und Werke deutscher Sprache, Vol. 6. (Bielefeld: Bertelsmann, 1990), p. 127; Franz Norbert Mennemeier, 'Vom Expressionismus zum Faschismus (Hanns Johst)', in Mennemeier, Modernes Deutsches Drama: Kritiken und Charakteristiken, Vol. 2 (Munich: Fink, 1975), p. 109

11. A synopsis of the play in English is included in J. M. Ritchie, 'Johst's Schlageter and the End of the Weimar Republic', in A. F. Bance, ed., Weimar Germany: Writers and Politics (Edinburgh: Scottish Academy Press, 1982), p. 153-67.

12. Hanns Johst, Schlageter (Munich: Langen-Müller, 1933), p. 134-5.

13. Quoted in Günther Rühle, Theater für die Republik: 1917-1933 im Spiegel der Kritik, rev. ed. (Berlin: Henschel, 1988), p. 1155.

14. Cf. Bernhard Diebold's review in the Frankfurter Zeitung, 25 April 1933, and Keienburg's piece in the Tägliche Rundschau, 22 April 1933; both reprinted in Rühle, Theater für die Republik, p. 1159.

15. See Martin Baumeister, Kriegstheater: Großstadt, Front und Massenkultur, 1914-1918 (Essen: Klartext, 2005).

16. See especially the works of Friedrich Bethge and Hans-Christoph Kaergel. The theme had also occurred specifically in two unperformed plays about Schlageter written in the immediate aftermath of the Ruhr crisis, discussed in Elisabeth Hillesheim, Die Erschaffung eines Märtyers: Das Bild Albert Leo Schlageters in der deutschen Literatur von 1923 bis 1945 (Frankfurt: Peter Lang, 1994), p. 75-88. Cf. also Klaus Theweleit's study of the psychology of völkisch men, Male Fantasies (Cambridge: Cambridge University Press, 1987).

17. See Barbara Piatti, Tells Theater: Eine Kulturgeschichte in fünf Akten zu Friedrich Schillers Wilhelm Tell (Basel: Schwabe, 2004).

18. See, inter al., Kortner, Aller Tage Abend, p. 361-2, and Kunstamt Kreuzberg and Institut für Theaterwissenschaft der Universität Köln, ed., Weimarer Republik (Berlin: Elefanten, 1977), p. 749.

19. Keienburg, Tägliche Rundschau, 22 April 1933; see also Diebold's perceptive comments in the Frankfurter Zeitung, 25 April 1933. 
20. Paul Fechter's often quoted remark about the 'totally different audience' should not be taken to mean that it was exclusively Nazi: some of the people Fechter mentions by name were, like Fechter himself, conservative, not Nazi. See Paul Fechter, Deutsche Allgemeine Zeitung, 22 May 1933.

21. See Fritz Stern, The Politics of Cultural Despair (Berkeley: University of California Press, 1974).

22. Cf. the impressions of Max Frisch during a visit to Germany in 1935: Frisch, 'Wunder des Lebens', in Oliver Lubrich, ed., Reisen ins Reich: Ausländische Autoren besichtigen Deutschland (Frankfurt: Eichborn, 2004), p. 89

23. 'Denn sich wehren und beim Sichwehren schließlich unterzugehen, das ist die tiefste Aufgabe des Lebens eines blutbewußten Menschen.' See W. Schloz, quoted in Uwe-Karsten Ketelsen, Heroisches Theater: Untersuchungen zur Dramentheorie des Dritten Reichs (Bonn: Bouvier, 1968)

24. Hanns Johst, 'Sei Schöpfung bedankt für Lorbeer und Ruhm!' (quoted in Düsterberg, Hanns Johst, p. 272) Johst had no intention of practising what he preached. When his own call-up papers for the Volkssturm arrived the home army of boys and old men that was to defend Germany in 1944-1945 - Johst promptly called on his friend Himmler to be exempted from service. The SS leader obliged.

25. Johst, Schlageter, p. 38.

26. Cf. Jay Winter, Sites of Memory, Sites of Mourning (Cambridge: Cambridge University Press, 1995).

27. Cf. the verdict of Thomas Mann's son Golo, who noted in his diary after seeing Johst's play, 'Vicious [and] nasty ... as expected ... [but also] quite clever and skilful in terms of dramatic technique.' See Golo Mann, Erinnerungen und Gedanken: eine Jugend in Deutschland (Frankfurt: Fischer, 1981), p. 531.

28. The phrase was coined by the dramatist Dietrich Eckart, Hitler's mentor in his Munich days. On Eckart's own contribution to the cultural assault on reason, see Claus-Ekkehard Bärsch, Die politische Religion des Nationalsozialismus: die religiöse Dimension der NS-Ideologie in den Schriften Dietrich Eckarts, Joseph Goebbels, Alfred Rosenbergs und Adolf Hitlers (Munich: Fink, 1998).

29. Hanns Johst, Ich glaube! Bekenntnisse (Munich: Langen, 1928), p. 17.

30. Herbert Frenzel, 'Das Drama der Entscheidung', Die Bühne, XI (20 Oct. 1938), p. 375.

31. Joseph Magnus Wehner, Vom Glanz und Leben deutscher Bühne (Hamburg: Hanseatische Verlagsanstalt, 1941), p. 340 .

32. Cf. 'Die Kunst ist ein unausgesprochener Staatsauftrag', in Frenzel, 'Das Drama der Entscheidung', p. 376.

33. H. Trautmann, 'Nationalerziehung', Volksbildung LXIV (1934), p. 13, quoted in Uwe-Karsten Ketelsen, Von heroischem Sein und völkischem Tod: Zur Dramatik des Dritten Reichs (Bonn: Bouvier, 1970), p. 346.

34. There was an artistic affinity between the two men: Piscator had actually directed an early Johst play. See Uwe-Karsten Ketelsen, Völkisch-nationale und nationalsozialistische Literatur in Deutschland 1890-1945 (Stuttgart: Metzler, 1976), p. 28

35. Note the similarity between the Communist position - e.g., Arthur Pieck, 'Kunst ist Waffe!', speech at the district meeting of the Workers' Theatre League in Leipzig, 25 Aug. 1929, reprinted in Bärbel Schrader and
Jürgen Schebera, Kunstmetropole Berlin 1918-1933 (Berlin: Aufbau, 1987), p. 233-5 - and that of the Nazis, for which see Rainer Schlösser, 'Die kulturelle Sendung Thüringens', speech in Altenburg, 8 Jan. 1936, in Die Bühne, 15 Jan. 1936, p. 337.

36. See, for instance, the striking praise from völkisch quarters for Soviet agitprop in 'Russische Agitationskunst', Deutsche Tageszeitung, 8 Oct. 1927 Abendausgabe. $\mathrm{Cf}$. also the cogent discussion of the underlying similarities in Ketelsen, Von heroischem Sein, p. 348.

37. See, for instance, 'Bundestag 1928 des ArbeiterTheater-Bundes', Die Rote Fahne, 13 April 1928, reprinted in Schrader, Kunstmetropole, p. 232.

38. Since Piscator's audiences were mostly middleclass, his efforts amounted to a triumph of hope over Marxism.

39. Eberhard Wolfgang Möller, 'Wandlungen des deutschen Theaters', Hochschule und Ausland, XIII, No. 4 (1935), p. 48.

40. On objections to 'New Sobriety', see Peter Ulrich Hein, Die Brücke ins Geisterreich: Künstlerische Avantgarde zwischen Kulturkritik und Faschismus (Reinbek: Rowohlt, 1992).

41. Paul Fechter, Deutsche Allgemeine Zeitung 14 Feb 1922: '. . . daß diese Nüchternheit aus innerer Armut kam, aus einem Herzen, das ... kein Empfinden hatte' On critical objections to 'unfeeling' productions in the theatre, see Günther Rühle, Theater für die Republik: 1917-1933 im Spiegel der Kritik, rev. ed. (Berlin: Henschel, 1988); on audience attendance, see the comments of Konrad Dussel, 'Theater in der Krise: Der Topos und die ökonomische Realität in der Weimarer Republik', in Lothar Ehrlich and Jürgen John, ed., Weimar 1930: Politik und Kultur im Vorfeld der NS-Diktatur (Cologne: Böhlau, 1998), p. 211-24.

42. Johst, Ich glaube!, p. 76

43. Becher to Alfred Andersch, 5 May 1948, quoted by Wolfgang Schivelbusch, In a Cold Crater: Cultural and Intellectual Life in Berlin, 1945-1948 (Berkeley: California University Press, 1998), p. 78.

44. Eberhard Wolfgang Möller, 'Die Geburt des Mythos und der Dichter', quoted in Stommer, Die inszenierte, p. 25

45. On this aspect in the so-called Thing plays, see William Niven, 'The Birth of Nazi Drama?: Thing Plays' in John London, ed., Theatre under the Nazis (Manchester: University Press, 2000), p. 54-95.

46. The point about the static quality of Nazi drama is discussed persuasively in Uwe-Karsten Ketelsen, Von heroischem Sein and his Heroisches Theater.

47. Johst, Schlageter, p. 36

48. Ibid., p. 29

49. The real-life Schlageter had briefly read economics after the war but had long abandoned his studies by 1923

50. Johst, Schlageter, p. 29

51. The text is published in Düsterberg, Hanns Johst, p. 198-202.

52. There is some merit in that argument. The real Schlageter was a nationalist but also a devout Catholic. That combination was often ground down by the reality of Nazi rule.

53. See, for instance, Holk Freytag, 'Ratlos in der Zirkuskupel? Schlageter in Wuppertal', Theater Heute, XXXIV, No, 1 (1993), p. 60 